\title{
The Pragmatics of Islamic Finance
}

The importance of articles on business related cases in academic disciplines cannot be overemphasized particularly for disciplines like Islamic banking and finance that are fundamentally different from the conventional one and are in emerging stage. The academia in Islamic finance is usually criticized for its abstraction and oversighting of the pragmatics of Islamic Finance. The detailed practical knowledge, in addition to theoretical discussions, occurs at different stages in actual practices in any area, and more so in case of Islamic finance. Such contextually oriented knowledge, may be better documented as narrative cases, could be more useful for both enhancing the depth of academic understanding of Islamic finance models as well as their application in the light of the reported narratives.

A narrative or a case of practice is a continues time-n-space wise connected factual or hypothetical discourse that constitutes sequential process of a situation or an incident, product application, treatment, decision or any other focus area in the related field. Such narratives serve as a complete knowledge packet. Meaningful narratives could relatively be more useful in communicating the depth and the procedure of Islamic financial transactions to the readers and more specifically to the trainees in any Islamic finance training and education programs.

The Center for Excellence in Islamic Finance, at the Institute of Management Sciences, (CEIF IMSciences), Pakistan initiated narrative studies development project in collaboration with the Riphah Centre for Islamic Business (RCIB), Riphah International University Islamabad and the International Shari 'ah Research Academy for Islamic Finance (ISRA), Kuala Lumpur to document various episodic processes on implementation of various Islamic financial products to enhance the practice oriented knowledge of different areas in Islamic finance. As part of the project, a Call was given for preparation and submission of narratives in any areas of Islamic Finance. The draft articles received were put in double-blind peer review process involving both internal and external reviewers. While within Pakistan, cases were sent to different experts, for foreign review the cases were mostly sent to the globally renowned Islamic finance research institution-ISRA, the Islamic finance research arm established under the auspices of the Bank Negara Malaysia.

The narratives revised in the light of peer reviewers' comments were presented by the researchers in a focused conference titled "The Pragmatics of Islamic Finance" held on 31st March 2018 at CEIF IMSciences. The conference was attended by experts in relevant areas, Shari' ah scholars and Mr. Muhammad Ayub, the Editor of the JIBM. Detailed and extensive discussion took place on the narratives and the authors were asked to revise in the light of the Conference deliberations. The finalized versions of the articles have been documented in the Special Issue of the JIBM that is in your hand. This Special Issue covers critical areas of Islamic finance as depicted in the following case studies:

1) The first article relates to the conversion of conventional banking into Islamic banking 
taking the Bank of Khyber (BoK), Pakistan as its case study. It demonstrates the involvement of political and social motivation in reconstructing the current conventional banking model. It highlights core challenges that the BoK team had to face. It also presented the value creation of the institutional intervention to be ethically sound, particularly shared value creation and collaborative efforts across the industry, from an institutional theory perspective. The narrative carries multiple implications for the Islamic banking professionals in terms of establishing an Islamic bank or converting a bank to be run on Islamic principles. It also offers practical insights on the process of business model reconstruction within the context of Islamic banking.

2) The second article pertains to deposits taking by Islamic banks. It explains how the banks issue Term Deposit Receipts (TDR) to get investment deposits based on the principle of mudärabah. It also elucidates how pools of funds are created and how profits are collected and distributed between the Bank as mudārib and the Deposits Pools, as well as among the deposits of various categories and sizes. The concept of daily product and weightage assigned to deposit play crucial role in this regard. The case also highlights how there could be queries about Islamic banking products from customers side before opening deposit accounts or investing money with the Islamic banks.

3) The third article elaborates on a unique real mushärakah based financing by an Islamic bank and the arrangements which Islamic banks in general would typically like to avoid. It highlights different types of risks associated with implementation of mushārakah based financing for the construction of housing flats. It goes through various interesting episodes of how the construction company and the bank managed to enter into mushärakah and how profits were distributed. It also highlights the different steps involved in implementing mushārakah financing which includes its associated risks, accounting process, and issues particularly those affecting compliance with Shari ${ }^{`}$ ah principles.

4) The fourth article is about corporate ijärah, which describes in detail how a corporate customer can avail this mode of financing through Shari'ah compliant procedure. It details the bank's procedure in dealing with corporate client from the first meeting with the firm's representative at the Islamic bank to discuss the firm's needs. In each step, the risk involved along with the mitigation of the risk is touched and discussed in detail. The focus of the case is to showcase the difference in the treatment between the corporate and retail consumer. In addition the repayment schedule for the client is also described in detail with the rent that an Islamic bank would earn.

5) The fifth article is on takâful assets. It shows how and why an asset should be covered in takâful, benchmarked at its market value, otherwise compensation will be on partial or proportionate basis should there be any occurrence of a defined loss. In an ijārah-based vehicle financing, an Islamic bank would take comprehensive takäful coverage for mitigation of the vehicle's related risk, like accidental damage, third party loss, theft and snatch. While 
takäful coverage is renewed on yearly basis, the bank would cover the vehicle on book value, which is usually less than their market value. This is usually due to the accelerated depreciation allocations. Therefore, when there is a loss, the takaful Company could only provide for proportionate compensation which is always far less than the actual loss. Ultimately this would cause the customer to suffer.

6) The sixth article depicts the process and the steps involved when a takäful agent meets and makes a new client. It starts with opening up a new policy till its closing or maturity. Importantly, it demonstrates the requirement by the takâful agent to collect information related to the client's financial worth, specific needs of takäful coverage and cost affordability. After considering the customers' need and affordability, takäful agent proposes two customized takâful plans to the potential customer who would then select one that best suits his needs. After going through several stages of processing, the takäful policy is then approved and the coverage starts. In approval process, multiple parties played their roles including the medical laboratory, the medical practitioner, the bank, the income tax authorities and others. The case is certainly useful in understanding the operational aspects of family takâful system.

7) The seventh article highlights the efficiency and effectiveness of AZ Investment Bank in meeting the specific and unique financing requirements of a customer, $\mathrm{O}$ Pharma. The financing requirements of $\mathrm{O}$ Pharma include importing raw material from China and producing final goods through the combination of mushärakah and ijārah against mortgage of a single security. To carry out such arrangement, the case study illustrates the process and parties involved namely the AZ Bank, the City Development Authority (CDA), the lawyer, the regional coordinator and incharge of the bank, the supplier in China and the shipment company. This study discusses various steps and roles of participants in the process of fulfilling the customer's requirements. The case study is unique in terms of how working capital finance is arranged through combination of mushärakah and leasing.

8) The eighth article is narrative of the muda arabah based Dana Gas sukūk default and its consequent legal proceedings and implications. Dana Gas stirred the global Islamic finance market when it announced in June 2017 that its muda $\operatorname{arabah}$ based $s u k \bar{u} k$ were no longer Shari' ah compliant due to changes in Shari'ah interpretation. Company claimed that the situation had made the suku $k$ unlawful in the UAE and therefore, the company would not be fulfilling its payment obligation under the $s u k \bar{u} k$, and would instead seek a restructuring of the instrument. The decision was contested by the $s u k \bar{u} k$ holders who appealed against it in the English court in the United Kingdom. On the other hand, Dana Gas opted for Sharjah court to proceed with litigation. The situation of dual litigation arose because while the $s u k \bar{u} k$ documentation is governed by the United Arab Emirates laws, the purchase undertaking, a crucial part of the arrangement, is governed by the English law. After months of litigation, the English court decided in favor of the $s u k \bar{u} k$ holders asking the Company to fulfill its payment obligations as the purchase undertaking is enforceable. On the contrary, the Sharjah court ordered the company not to follow the orders of the UK court and instead follow the 
instructions of the UAE court. The question, whether the șukük is Shari'ah compliant or has ceased to be so, is to be decided by it and not by the English court. This case study also describes other important parts of the episode like the attempt for an out-of-court restructuring of the $s u k \bar{u} k$, the causes for the failure of restructuring attempts, the behavior of the $s u k \bar{u} k$ issuer, $s u k \bar{u} k$ investors and the overall legal uncertainty in $s u k \bar{u} k$ documentation and default incident.

9) The ninth article depicts the situation of a company whose founding CEO had a firm determination to extricate the company from the interest based borrowing. He deputed his CFO to find a way out, through Shari 'ah, to arrange its existing debt and further financing through the Islamic modes of financing. The case study discusses scenarios, reasons and modalities of availing the most preferable mode of financing i.e. mushärakah by issuing the Mushārakah based Term Finance Certificates (MTFCs).

10) The tenth article pertains to financial reporting that has to be fair and transparent for just distribution of profits among the various stakeholders. Viewed from the accountant's perspective, the case discusses various techniques used for manipulation and method to bridge the gap between theory and practice of financial reporting based on the true and fair view of financial reporting practices. The lack of well-defined accounting model and violation of its assumptions would inevitably lead to manipulated financial statements.

11) The eleventh article describes how Akhuwat, a unique and world renowned Islamic microfinance NGO, has significantly reduced the high operating cost through its innovative operation model of cooperation and mutual help embedded in the non-market part of Islamic economics. In conventional micro finance models, high operating cost, usually considered as unavoidable which ultimately transferred to the poor clients as direct credit supply cost. However Akhuwat with its Head Office at Lahore, Pakistan channelized qard al-hasan (interest/return free loans) to the poor and financially marginalized communities through technically viable, cost efficient, socially responsible, and religiously compatible process. It explains how Akhuwat devised mechanism to minimize operating cost to increase the chance of providing interest free loans to the maximum number of deserving people on sustainable basis, while putting minimum financial burden on the organization. This style of financing arrangement distinguishes Akhuwat model of Islamic micro finance from all other models operating in various parts of the world. The successful Akhuwat model is being replicated in other regions and by other similar organizations.

Premised on the summary of the case studies above, we are confident that the Special Issue of the JIBM on the practices of Islamic finance would be welcomed both by the academic circles as well as practitioners of Islamic finance in understanding the pragmatic of Islamic finance. It is expected to narrow the gap between the abstract theory and concrete practice of Islamic finance through historically established scientific narrative methodology. It might also help in addressing the lacuna, both from the Shari 'ah and the professional perspectives, in the products and the processes involved. 
We believe that the articles contained in the Special issue would provide sufficient scholarly base for enhancing the episodic or circumstantial knowledge of Islamic finance. The maiden joint effort of the CEIF IMSciences, ISRA and the JIBM would go a long way in expanding the frontiers of education and training in the emerging field of Islamic finance in two ways: one by instigating the increasing number of education, training and research institutions to follow the move to deliver practice oriented knowledge, and the other by publishing narratives-based special Issues of the academic and professional Journals for guidance of parties involved.

Muhammad Ayub, Editor (JIBM)

Dr. Karim Ullah, Guest Editor (IMSciences, Peshawar, Pakistan)

Dr. Noor Suhaida Kasri, Guest Editor (ISRA, KL, Malaysia) 